\title{
The Conservation Status of Hong Kong's Tree Flora
}

\author{
ZHUANG XUEYING \\ Department of Plant Protection, South China Agricultural University, Guangzhou 510642 \\ RICHARD T. CORLETT \\ Department of Ecology and Biodiversity, University of Hong Kong, Pokfulam Road, Hong Kong
}

(Received October 30, 1995; Revised April 10, 1996)

\section{ABSTRACT}

Since 1840, 333 native tree species have been recorded in Hong Kong. However, as a result of past and present land use practices, many forest tree taxa are in danger of extinction. Since the late 1970s, a systematic conservation system has been established in Hong Kong. Most of the forest and many plant species are protected by law. This paper reports the current conservation status of the tree flora of Hong Kong, based on a study of forest ecology and floristics between $1989 \sim 1996$. The relevance of Hong Kong's experience to the conservation of China's tree flora is also briefly discussed.

Key words Hong Kong, China, trees, diversity, conservation

\section{Introduction}

Hong Kong lies on the south coast of China between latitudes $22^{\circ} 09^{\prime}-22^{\circ} 37^{\prime} \mathrm{N}$ and longitudes $113^{\circ} 52^{\prime} \sim 114^{\circ} 30^{\prime} \mathrm{E}$. It consists of a section of the Chinese mainland (Kowloon and the New Territories, $782 \mathrm{~km}^{2}$ ) and numerous islands, of which the largest are Lantau Island $\left(142 \mathrm{~km}^{2}\right)$ and Hong Kong Island $\left(78 \mathrm{~km}^{2}\right)$. The total area is $1076 \mathrm{~km}^{2}$. The topography is extremely rugged, reaching $957 \mathrm{~m}$ at the highest point, Tai Mo Shan, in the New Territories. Hong Kong's population of 6 million people is concentrated on the limited natural flat land, which has been extended by coastal reclamation.

Hong Kong's climate has both tropical and subtropical features, with both temperature and rainfall highly seasonal. The winter, however, is neither very cold nor very dry, so the original forest cover of Hong Kong was probably largely evergreen. There is archaeological evidence of human occupation for at least 6000 years (Meachem 1994) but no direct evidence for when the major deforestation occurred. Both Chinese and European accounts of the region in the 17th century describe or imply a largely deforested landscape but it is possible that considerable clearance occurred much earlier (Dudgeon and Corlett 1994). By 1841, at the start of British administration, there were only two substantial patches of forest on Hong Kong Island, totalling less than 100 hectares, with additional small patches in deep ravines. Subsequent changes have included both the negative impacts of expanding human population and e-

* This study was supported by the Rockefeller Brothers Fund and Department of Botany, University of Hong Kong. We greatly appreciate the help we received from the staff of the Hong Kong Herbarium, Agriculture and Fisheries Department, and the staff of the Department of Botany, University of Hong Kong

- 36 . 
conomic development, and the positive influence of conservation policies.

In this paper, the conservation status of Hong Kong's tree flora is described and the impact of past and present conservation policies is discussed. Recommendations are then made for enhancing the conservation of native tree diversity in Hong Kong and in those parts of South China which share a similar history of human impact.

\section{Conservation history of Hong Kong}

There seem to have been few attempts by the colonial administration to protect the existing forest area, either on Hong Kong Island or, later, in the New Territories. The only forest patches which have survived from the nineteenth century are those behind rural villages which are protected by the local inhabitants for reasons of feng shui. From the 1870s, however, the Government started large-scale afforestation, initially on Hong Kong Island but extending to the New Territories after 1900. Most trees planted or sown in-situ were the native Pinus massoniana, but many other species, both native and exotic, were planted on a small scale. By 1938, $70 \%$ of Hong Kong Island was covered in Government plantations and there were several large afforested areas in the New Territories. An additional $200 \mathrm{~km}^{2}$ was covered in leased forestry lots used for producing firewood. Almost all the plantations were cut down during the Japanese Occupation. Afforestation started again after the war on a smaller scale. Planting was concentrated in the water catchment areas and increasingly relied on exotic species, rather than the native pine.

The Hong Kong Government was very late in setting up a formal protected area system and the first "Country Park" was not established until 1976. Country Parks and Special Areas were established for both conservation and recreation. Today the 21 Country Parks and the 3 Special Areas which are not within Country Parks protect $41320 \mathrm{hm}^{2}$ of countryside: slightly over $40 \%$ of the total land area of the Territory . Outside the Country Park system, a coastal area, Mai Po Marshes in the Northwest New Territories, is protected as a Restricted Area under the Wild Animals Protection Ordinance and a permit is required for entry. In addition, there are 58 Sites of Special Scientific Interest (SSSI), although almost half of these are inside other protected areas. Most SSSIs are small areas which are protected because of their biological or other scientific interest. SSSIs are basically an aid to planning and currently receive no special management. The Town Planning Ordinance also provides for additional landscape protection categories for areas where development should be restricted.

Hong Kong also has legislation which protects named species of plants and animals anywhere in the territory. Protection of plant species started in 1913 with a law to prohibit collecting and selling nine plant taxa with ornamental value, including all species of Rhododendron, Litsea cubeba, Enkianthus quinqueflorus and Manglietia fordiana (Dudgeon and Corlett 1994). In 1936, the list of protected plants was extended to include more than $25 \%$ of the flora, including all Fagaceae and such widespread species as Sterculia lanceolata. The current list of species, protected under the Forestry Regulations of the Forests and Countryside Ordinance, is considerably shorter but includes 27 tree species (Dudgeon and Corlett 1994). This list of protected species is a useful supplement to the protected area system.

In addition to protected areas and species, conservation of the flora and fauna is also promoted by the Environmental Impact Assessments ( $I I A)$ required before major developments, even on private land. The presence of rare plant species should be recorded during the 
EIA and the developers are required to prevent or minimise damage to all the protected species.

\section{$3 \quad$ Floristic diversity of Hong Kong forest}

Today, approximately $14 \%$ of Hong Kong $\left(150 \mathrm{~km}^{2}\right)$ is covered in forest: one third plantations and two-thirds natural forest (Ashworth et al. 1993). Although the native $P i$ nus massoniana was the most widely-planted species in the past, most trees of this species in Hong Kong have been killed by the introduced Pinewood Nematode (Bursaphelenchus $x y$ lophilus) and most surviving plantations consist of exotics (Dudgeon and Corlett 1994). The commonest species are Acacia confusa, Lophostemon confertus (previously called Tristania conferta), Melaleuca quinquenervia (often confused with $M$. leucadendron) and $P$. elliottii. Most plantations consist initially of a single tree species but diversity increases with age as native species invade and some of the oldest plantations are hard to distinguish from natural secondary forests. Much of the existing natural secondary forest, in fact, consists of trees which became established under a canopy of $P$. massoniana .

Natural forest in Hong Kong can be divided into three major types, although stands with intermediate characteristics do exist (Zhuang 1993). The oldest forests in Hong Kong are feng shui woods, protected near villages or temples for the purpose of geomancy by the local residents. Many of these woods are more than 50 years old and some, at least, have existed for several centuries. The origin of feng shui woods is uncertain: by protection of existing natural forest, by planting, by succession or, most probably, by a variable combination of these sources. The majority of the natural forest in Hong Kong has developed since 1945 by succession. There is a gradual change in forest floristics around $500 \mathrm{~m}$ altitude (Zhuang 1993) so two types are recognised: lowland secondary forest below $500 \mathrm{~m}$ and montane forest above.

The floristic diversities of the three forest types have different, but overlapping, ranges (Table 1). In general, feng shui woods have the highest species richness, diversity and evenness, presumably as a result of their greater age. The lowland and montane secondary forests have similar ages but montane forest has somewhat higher mean diversity and evenness possibly because the complex topography and inaccessibility of upland areas allowed more trees to survive during the past centuries of intense human impact.

Table 1 Species richness ( $S$ ), Shannon diversity index $(H)$, and equitability $(J)$ of three major types of forest in Hong Kong

\begin{tabular}{ccccc}
\hline Forest type & No.of samples & $S$ mean $\left(\right.$ std $\left.^{2}\right)$ & $H$ mean (std) & $J$ mean (std) \\
\hline $\mathrm{FSW}^{3}$ & 13 & $32(8)$ & $2.99(0.37)$ & $0.84(0.06)$ \\
$\mathrm{LSF}^{4}$ & 25 & $27(6)$ & $2.53(0.32)$ & $0.77(0.07)$ \\
$\mathrm{MF}^{3}$ & 6 & $26(4)$ & $2.66(0.14)$ & $0.82(0.05)$ \\
\hline
\end{tabular}

1: number of plots sampled of each forest type (plot size $=4 \times 100 \mathrm{~m}^{2}$ ); 2: std = standard deviation; 3 . feng shui woods; 4: lowland secondary forest; 5: montane forest; $\mathrm{S}=$ total number of species per plot; $\mathrm{H}=-\sum \mathrm{Pi}^{*} \ln P i, \mathrm{Pi}_{i}=$ proportion of total individuals in the ith species; $J=H / \ln S$ (Begon et al. 1986) 
A total of 333 tree species, belonging to 61 families and 162 genera, have been recorded in Hong Kong since 1841 (Zhuang 1993). Of these, 50 species were not seen during the course of a forest survey by Zhuang (1993) while another 47 species were seen at only one site. Among the species seen, 161 were found within the 44 forest plots (each $20 \times 20 \mathrm{~m}^{2}$ ) surveyed and an additional 102 species were seen outside the plots. The current secondary forests are mainly dominated by some common pioneer species. Many rare species are confined to a few remote ravine woodlands or those on steep cliffs. Among the 50 species not seen during the course of the study, the family with most species was the Fagaceae. Almost half of the recorded species in this family were not seen and another $25 \%$ were seen only at one site.

The status of the rare and endangered plants of Hong Kong varies with the species. Some species are found at only a few sites but are abundant where they occur, such as $A$ mentotaxus argotaenia, Illicium angustisepalum, Persea kadooriei, and Michelia chapensis. Such species may not be in immediate danger of extinction but are very vulnerable to habitat destruction. Some other species are widespread but nowhere abundant, such as Persea grijsii, Beilschmiedia tsiangii, Sinosideroxylon wightianum, and Cinnamomum validinerve. The most endangered species are those which occur in low numbers at only one or a few sites. Most of the rare and endangered species in Hong Kong belong to this category. A few species are probably extinct, such as Syzygium odoratum and Beilschmiedia fordii, which were only recorded in the Happy Valley Woods in the nineteenth century. These woods were subsequently cleared some time before 1900 .

Considering their distributions as a whole, many of the rare species in Hong Kong are globally rare. Such species include Amentotaxus argotaenia, Camellia crapnelliana, $C$. granthamiana, Castanopsis concinna, C. kawakamii, and Tetrathryrium subcordatum, which are rare and legally protected in China. However, there are also a few species which are rare in China but common in Hong Kong. The clearest example is Artocarpus hypargyrea, which is rare and protected in China, but is quite common in Hong Kong. There are also species which are rare in Hong Kong but abundant elsewhere in China.

Two tree species, Persea kadooriei and Tsiangia hongkongensis, are apparently endemic to Hong Kong. The distributions of both of them are very restricted. $T$. hongkongensis is possibly extinct because it has not been seen again since two type specimens were collected in the 1850s (But et al. 1986).

Combining information from the forest survey, herbarium specimens, local botanical literature, and personal communications from local botanists, a total of 123 recorded tree species can be considered rare or extinct in Hong Kong (Table 2). This total includes the 50 species not seen during the course of this study, 47 species seen at only one site, and 26 species seen at more than one site but with very few individuals or very vulnerable to destruction of their habitats.

Among the rare or extinct species, the habitat of 15 species is uncertain. Of the others, 90 species are recorded from forest while another 16 species are recorded in thickets or streamsides. Of the species seen in forest, at least 30 species are apparently confined to either montane forest or well-developed feng shui woods. The families with most threatened species are Fagaceae (20 spp.), Lauraceae (16 spp.), Theaceae (11 spp.), Magnoliaceae 
(8 spp.) and Hamamelidaceae (6 spp.) .

Table 2 Rare, threatened or extinct tree species in Hong Kong

\begin{tabular}{|c|c|c|c|c|}
\hline Family & Species & Occurrence & Status & Habitat \\
\hline \multirow[t]{3}{*}{$\overline{\text { Aceraceae }}$} & Acer reticulatum & I & rare & woodland \\
\hline & A. sino-oblongum & I & vulnerable & FSW \\
\hline & A. tutcheri & I & rare & MF \\
\hline \multirow[t]{4}{*}{ Aquifoliaceae } & Ilex dasyphylla & I & rare & MF \\
\hline & I. graciliflora & II & vulnerable & woodland \\
\hline & I. kwangtungensis & I & rare $\quad$. & woodland \\
\hline & I. macrocarpa & $\mathrm{O}$ & rare & roadside \\
\hline \multirow[t]{3}{*}{ Boraginaceae } & Cordia dichotoma & $\mathrm{O}$ & rare & woodland \\
\hline & Ehretia thyrsiflora & $\mathrm{O}$ & rare & near stream \\
\hline & E. Longifolia & II & vulnerable & woodland \\
\hline Cornaceae & Dendrobenthamia hongkongensis * & I & rare & woodland \\
\hline \multirow[t]{2}{*}{ Elaeocarpaceae } & Elaeocarpus dubius & II & rare & FSW \\
\hline & E. japonicus & I & vulnerable & MF \\
\hline \multirow[t]{2}{*}{ Ericaceae } & Lyonia ovalifolia & $\mathrm{O}$ & rare & $?$ \\
\hline & Rhododendron moulmainense & I & rare & woodland \\
\hline \multirow[t]{3}{*}{ Euphorbiaceae } & Antidesma fordii & I & vulnerable & FSW \\
\hline & Endospermum chinense & II & vulnerable & FSW \\
\hline & Macaranga sampsonii & II & vulnerable & FSW \\
\hline \multirow[t]{3}{*}{ Fabaceae } & Gleditsea sinensis & $\mathrm{O}$ & rare & $?$ \\
\hline & Millettia pulchra & 0 & rare & woodland \\
\hline & Ormosia indurata & $\mathrm{O}$ & rare & woodland \\
\hline \multirow[t]{20}{*}{ Fagaceae } & Castanopsis carlesii & $\mathrm{O}$ & rare & near catchment \\
\hline & C. concinna & II & rare & woodland \\
\hline & C. eyrei & $\mathrm{O}$ & rare & $?$ \\
\hline & C. kawakamii & $\mathrm{O}$ & rare & woodland \\
\hline & C. lamontii & $\mathbf{I}$ & vulnerable & woodland \\
\hline & C. sclerophylla & $\mathrm{O}$ & rare & $?$ \\
\hline & Lithocarpus attenuatus & $\mathrm{O}$ & extinct? & Happy Valley \\
\hline & L. elizabethae & I & rare & woodland \\
\hline & L. fenestratus & II & rare & near stream \\
\hline & L. haipinii & I & rare & woodland \\
\hline & L. harlandii & $\mathrm{O}$ & rare & woodland \\
\hline & $L:$ irwinii & $\mathrm{O}$ & rare & woodland \\
\hline & L. iteaphylla & $\mathrm{O}$ & rare & woodland \\
\hline & L. konishii & $\mathrm{O}$ & rare & $?$ \\
\hline & L. macilentus & $\mathrm{O}$ & rare & $?$ \\
\hline & L. naindarum & $\mathrm{O}$ & rare & $?$ \\
\hline & L. rhombocarpus & $\mathrm{O}$ & rare & $?$ \\
\hline & Quercus blakei & $\mathrm{O}$ & rare & woodland \\
\hline & Q. fabri & $\mathrm{O}$ & rare & woodland \\
\hline & Q. litseoides & I & rare & thickets \\
\hline \multirow[t]{3}{*}{ Flacourtiaceae } & Casearia villilimba & II & rare & woodland \\
\hline & Flacourtia rukam & I & rare & FSW \\
\hline & Xylosma longifolia & I & rare & FSW \\
\hline \multirow[t]{3}{*}{ Hamamelidaceae } & Altingia chinensis & II & vulnerable & woodland \\
\hline & A. gracilipes var. serrulata & II & rare & near stream \\
\hline & Corylopsis multiflora & I & rare & MF \\
\hline
\end{tabular}


Table 2 (Continued)

\begin{tabular}{|c|c|c|c|c|}
\hline & Exbucklandia tonkinensis & I & rare & MF \\
\hline & Sycopsis tutcheri & $\mathrm{O}$ & rare & ravine woods \\
\hline & Tetrathyrium subcordatum & $\mathrm{O}$ & rare & thickets \\
\hline \multirow[t]{4}{*}{ Lauraceae } & Beilschmiedia fordii & $\mathrm{O}$ & rare & Happy Valley \\
\hline & B. tsangii & II & rare & ravine woods \\
\hline & Cinnamomum applianum & I & rare & MF \\
\hline & C. japonicum & II & rare & thickets \\
\hline \multirow[t]{12}{*}{ Lauraceae } & C. validinerve & II & vulnerable & woodland \\
\hline & Cryptocarya chinensis & II & vulnerable & woodland \\
\hline & C. concinna & II & vulnerable & woodland \\
\hline & Lindera aggregata & I & rare & woodland \\
\hline & L. megaphylla & $\mathrm{O}$ & rare & FSW \\
\hline & L. metcalfiana & I & rare & MF \\
\hline & L. nacusua & I & rare & thickets \\
\hline & Litsea elongata & $\mathrm{O}$ & rare & near stream \\
\hline & L. variabilis & $\mathrm{O}$ & rare & woodland \\
\hline & Neolitsea levinei & I & rare & MF \\
\hline & Persea grijsii & II & vulnerable & woodland \\
\hline & P. kadooriei & I & rare & woodland \\
\hline Lythraceae & Lagerstroemia fordii ${ }^{*}$ & $\mathrm{O}$ & rare & woodland \\
\hline \multirow[t]{8}{*}{ Magnoliaceae } & Illicium angustisepalum * & I & rare & MF \\
\hline & I. dunnianum ${ }^{*}$ & II & vulnerable & near stream \\
\hline & I. micranthum" & I & rare & MF \\
\hline & Magnolia championii & II & vulnerable & MF \\
\hline & M. fistulosa* & I & rare & MF \\
\hline & Manglietia fordiana" & I & rare & MF \\
\hline & Michelia chapensis * & $\mathrm{I}$ & rare & MF \\
\hline & M. maudiae* & $\mathrm{O}$ & rare & MF \\
\hline Malvaceae & Thespesia populnea & II & vulnerable & coastal woods \\
\hline Meliaceae & Dysoxylum hongkongense & II & rare & woodland \\
\hline \multirow[t]{4}{*}{ Moraceae } & Artocarpus styracifolius & II & vulnerable & woodland \\
\hline & A. tonkinensis & II & rare & FSW \\
\hline & Cudrania tricuspidata & $\mathrm{O}$ & rare & $?$ \\
\hline & Ficus lankokensis & I & rare & woodland \\
\hline \multirow[t]{3}{*}{ Myrtaceae } & Acmena acuminatissima & $\mathrm{O}$ & rare & woodland \\
\hline & Decaspermum gracilentum & $\mathrm{O}$ & rare & $?$ \\
\hline & Syzygium odoratum & $\mathrm{O}$ & extinct ? & Happy Valley \\
\hline \multirow[t]{2}{*}{ Olacaceae } & Schoepfia chinensis & I & rare & woodland \\
\hline & S. jasminoides & $\mathrm{O}$ & rare & nullah \\
\hline \multirow[t]{5}{*}{ Oleaceae } & Chionanthus retusa & $\mathrm{O}$ & rare & $?$ \\
\hline & Fraxinus griffithii & I & rare & MF \\
\hline & Olea dioica & I & rare & FSW \\
\hline & Osmanthus marginatus & I & rare & woodland \\
\hline & O. matsumuranus & II & rare & woodland \\
\hline Pinaceae & Keteleeria fortunei ${ }^{*}$ & I & rare & coastal wood \\
\hline Podocarpaceae & Podocarpus neriifolia & I & rare & thickets \\
\hline Rhizophoraceae & Carallia pectinifolia & I & rare & FSW \\
\hline Rosaceae & Laurocerasus marginata & $\mathrm{O}$ & rare & woodland \\
\hline \multirow[t]{3}{*}{ Rubiaceae } & Cephalanthus occidentalis & $\mathrm{O}$ & rare & near stream \\
\hline & Randia acuminatissima & I & rare & woodland \\
\hline & Tsiangia hongkongensis & $\mathrm{O}$ & extinct? & $?$ \\
\hline
\end{tabular}


Table 2 (Continued)

\begin{tabular}{|c|c|c|c|c|}
\hline \multirow[t]{4}{*}{ Rutaceae } & Skimmia arborescens & I & rare & ravine \\
\hline & Zanthoxylum ailanthoides & $\mathrm{O}$ & rare & near fish pond \\
\hline & $Z$. myriacanthum & I & rare & thickets \\
\hline & $Z$. ovalifolium & $\mathrm{O}$ & rare & $?$ \\
\hline \multirow[t]{2}{*}{ Sabiaceae } & Meliosma fordii & $\mathrm{O}$ & rare & woodland \\
\hline & M. squamulata & I & rare & MF \\
\hline Sapotaceae & $\begin{array}{l}\text { Chrysophyllum lanceolatum } \\
\text { var. stellatocarpon }\end{array}$ & II & vulnerable & FSW \\
\hline Simarubaceae & Ailanthus fordii * & 1 & rare & ravine woods \\
\hline \multirow[t]{2}{*}{ Styracaceae } & Alniphyllum fortunei & $\mathrm{O}$ & rare & woodland \\
\hline & Rehderodendron kwangtungense " & 1 & rare & woodland \\
\hline Symplocaceae & Symplocos pendula var. hirtistylis & 0 & rare & woodland \\
\hline Taxaceae & Amentotaxus argotaenia & 1 & rare & $\mathrm{MF}$ \\
\hline Taxodiaceae & Glyptostrobus pensilis & $\mathrm{O}$ & rare & $?$ \\
\hline \multirow[t]{11}{*}{ Theaceae } & Adinandra jubata & I & rare & ravine woods \\
\hline & Camellia assimilis * & II & rare & woodland \\
\hline & C. crapnelliana & $\mathrm{O}$ & rare & woodland \\
\hline & C. granthamiana & $\mathrm{O}$ & rare & woodland \\
\hline & C. hongkongensis" & I & rare & woodland \\
\hline & Eurya distichophylla & $\mathrm{O}$ & rare & woodland \\
\hline & Hartia sinensis & $\mathrm{O}$ & rare & $?$ \\
\hline & H. villosa & $\mathrm{O}$ & rare & woodland \\
\hline & Ternstroemia microphylla & 1 & rare & ravine woods \\
\hline & Tutcheria championii * & II & rare & woodland \\
\hline & T. microcarpa" & 1 & rare & woodland \\
\hline Verbenaceae & Callicarpa longissima & $\mathrm{O}$ & rare & thickets \\
\hline
\end{tabular}

1. Occurrence: $\mathrm{O}=$ not seen, $\mathrm{I}=$ seen at one site, $\mathrm{II}=$ seen at more than one site;

2. Habitat: $\mathrm{FSW}=$ feng shui wood, MF = montane forest, Happy Valley= Happy Valley Wood, ? = unknown. * species is protected in Hong Kong.

\section{Major problems, recommendations and implication of this study}

The conservation of nature in Hong Kong has improved considerably since the late 1970 s, but there are still many problems. The principal threat to feng shui woods is the increasing development of previously remoie rural areas. Most other forest areas are within Country Parks but hill fires are still a threat, particularly to isolated forest fragments. The widespread planting of exotic, fast-growing species in plantations is also an adverse factor for the conservation of the native tree flora. Most of current plantations in Hong Kong consist of exotic species, such as Acacia spp., Pinus spp. and Lophostemon confertus. These plantations have a purely ecological function as timber production in Hong Kong is uneconomic. However, they are unfavourable for restoration of native biodiversity because of their low tree diversity and simple structure. The use of exotic species may be necessary on the most degraded sites but very little research has been done on the potential of the native tree flora in such situations. Further research on the silvicultural characteristics of native species is urgently required.

In addition, although many rare plant species and their habitats are legally protected in Hong Kong, others are not. Among these 123 rare and threatened tree species, only 21 species are under protection of the Hong Kong Forestry Regulation (Dudgeon and Corlett 
1994). Many really rare and endangered species have not been included in the list of protected plants of Hong Kong because of the lack of detailed knowledge of the distribution status of the local flora. The most conspicuous case is the Fagaceae. More than half the species in this family are threatened but none are on the protected species list. Existing protected areas include most of the lowland secondary forest and almost all the montane forest. Feng shui woods, however, are poorly represented in the protected area system and many of the best examples currently receive no legal protection at all. A comprehensive biodiversity survey of Hong Kong, which is being conducted by the Department of Ecology and Biodiversity of the University of Hong Kong, aims to fill some of these gaps by identifying species and habitats in need of protection.

Experience from Hong Kong is most easily applied in those areas of Southern China which share both a similar physical environment and a similar history of human impact. Despite the differences in scale and in economic factors between Hong Kong and southern China, two conclusions from this study in Hong Kong are probably of general application in the region. Firstly, this study has shown that a very diverse tree flora can persist, apparently for hundreds of years, in tiny forest fragments. Similar forest fragments in largely deforested areas of Southern China should be given a high priority for conservation. Secondly, the study has demonstrated that even badly degraded hill slopes can develop forest in 30 40 years by natural succession if they are protected from fire and cutting. Although this process is slower than active planting of trees, the resulting forest has greater structural and floristic diversity than most plantations. As a result, it is better for supporting wildlife and is likely to be more stable in the long-term. Plantations in many areas of China suffer serious problems from insect pests, a fact which has been attributed to their very low bird populations (Richardson 1990). Indeed, the positive influence of insectivorous birds on tree growth has been shown experimentally in the United States (Marquis and Whelan 1994). It may be possible to combine the advantages of high-yielding plantations with those of diverse, natural secondary forests, by planting a mixture of native and exotic species. However, for this to be possible, it is essential that conservation of China's rich, native tree flora is given a high priority.

\section{REFERENCES}

Ashworth J M, R T Corlett, D Dudgeon, D S Melville, W S M Tang, 1993. Hong Kong flora and fauna: computing conservation. Hong Kong: Worldwide Fund for Nature

Begon M, J L Harper, C R Townsend, 1986. Ecology: individuals, populations and communities. London: Blackwell Scientific Publications, 593 595

But P P, H H Hsue, P T Li, 1986. Tsiangia, a new genus on Gaertnera hongkongensis (Rubiaceae). Blumea, 31 : $309 \sim 312$

Dudgeon D, R T Corletr, 1994. Hills and streams. Hong Kong: Hong Kong University Press, $1 \sim 224$

Marquis R J, C J Whelan, 1994. Insectivorous birds increase growth of white oak through consumption of leaf-chewing insects. Ecology, 75(7): 2007 -2014

Meachem W, 1994. Archaeological investigations on Chek Lap Kok Island. Hong Kong: Hong Kong Archaeological Society, $1-45$

Richardson S D, 1990. Forests and forestry in China. Washington D C: Island Press, 221 224

Zhuang X, 1993. Forest succession in Hong Kong. Hong Kong: University of Hong Kong 